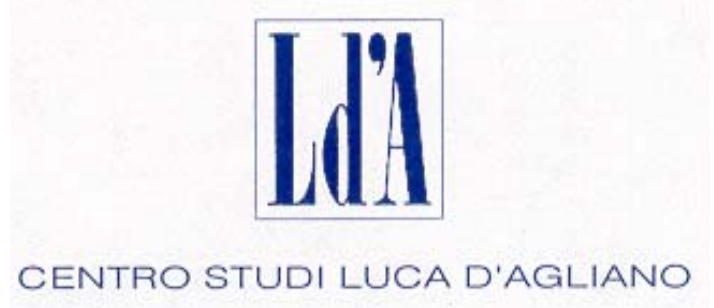

WWW.DAGLIANO.UNIMI.IT

\author{
CENTRO STUDI LUCA D'AGLIANO \\ DEVELOPMENT STUDIES WORKING PAPERS
}

N. 197

March 2005

\title{
Gifted Kids or Pushy Parents? \\ Foreign Acquisitions and Plant Performance in Indonesia
}

\author{
Jens Matthias Arnold* \\ Beata Smarzynska Javorcik**
}

* World Bank and Bocconi University

**World Bank and CEPR 


\title{
Gifted Kids or Pushy Parents?
}

\section{Foreign Acquisitions and Plant Performance in Indonesia}

\author{
Jens Matthias ARNOLD* and Beata Smarzynska JAVORCIK ${ }^{* *}$
}

April 20, 2005

\begin{abstract}
This paper uses micro data from the Indonesian Census of Manufacturing to analyze the causal relationship between foreign ownership and plant productivity. To control for the possible endogeneity of the FDI decision, a difference-in-differences approach is combined with propensity score matching. An advantage of this method, which has not been previously applied in this context, is the ability to follow the timing of observed changes in productivity and other aspects of plant performance. The results suggest that foreign ownership leads to significant productivity improvements in the acquired plants. The improvements become visible in the acquisition year and continue in subsequent periods. After three years, the acquired plants outperform the control group in terms of productivity by 34 percentage points. The data also suggest that the rise in productivity is a result of restructuring, as acquired plants increase investment outlays, employment and wages. Foreign ownership also appears to enhance the integration of plants into the global economy through increased exports and imports.
\end{abstract}

Keywords: foreign direct investment, productivity JEL classification: F23, O33, D24

\footnotetext{
* World Bank and Bocconi University, 1818 H Street, NW; MSN MC3-303; Washington, DC, 20433. Email: jarnold1@worldbank.org.

** World Bank and CEPR, 1818 H Street, NW; MSN MC3-303; Washington, DC, 20433. Email: bjavorcik@worldbank.org.

The authors would like to thank Mona Haddad, Sjamsu Rahardja and Kai Kaiser for making the data available and John Romalis for information on domestic M\&As in Indonesia. We are also indebted to Mary Amiti, Ana Fernandes, Aart Kraay, Jan de Loecker, Gianmarco Ottaviano and seminar participants at the World Bank International Trade Seminar, the Inter-American Development Bank, the European Research Workshop on International Trade, Katholieke Universiteit Leuven, Syracuse University, the Fourth Workshop of the Regional Integration Network in Montevideo sponsored by LACEA and the World Bank-LSE Conference on Industrialization and Development in London for helpful suggestions. Moreover, we thank Edwin Leuven, Sascha Becker and Andrea Ichino for valuable advice on the empirical implementation and Hans Shrader for his support and advice. The findings, interpretations and conclusions expressed in this paper are entirely those of the authors. They do not necessarily represent the view of the World Bank or its Executive Directors.
} 


\section{Introduction}

The conventional wisdom suggests that multinational companies have an advantage over local firms, which allows them to offset the extra cost of operating in distant and unfamiliar markets. However, is the superior performance of foreign affiliates due to the intrinsic advantage of a 'pushy' foreign parent company, or are foreign investors simply good at picking the best performing local plants as acquisition targets (the 'gifted kids' in our metaphor)? Recently, the application of sophisticated econometric techniques to longitudinal micro data has cast some doubt on an intuitive positive answer to these questions, often taken for granted by economists and policymakers. ${ }^{1}$ As Harris and Robinson (2003) remark, if foreign ownership per se is not associated with a productivity advantage, "then it is difficult to see how FDI can have a positive impact on overall (..) productivity and thus growth" in the host country.

This study analyzes the causal link between foreign ownership and plant performance in Indonesia. While to the best of our knowledge this question has not been examined in a developing country context, ${ }^{2}$ there are several reasons to expect that the effect of foreign ownership will be particularly pronounced in the developing world. First, the difference in technological sophistication between foreign investors and plants they acquire is likely to be larger in developing countries than in industrialized economies. Second, foreign direct investment (FDI) is widely considered to be a key mechanism of cross-border technology transfer. ${ }^{3}$ The plausibility of this mechanism is supported by theoretical arguments stressing the importance of intangible assets, transfer of technology from headquarters to foreign affiliates (e.g., Markusen 1995) and the fact that most of the world's R\&D effort is undertaken by multinational companies. Additionally, recent theoretical work by Helpman et al. (2004) on heterogenous firms suggests that multinationals come from the upper part of the productivity distribution of firms in their country of origin. ${ }^{4}$

\footnotetext{
${ }^{1}$ Harris and Robinson (2003) demonstrate that foreign investors acquire the best performing firms in the UK, but subsequently the acquired firms do not reap any benefits from foreign ownership. Using Italian data, Benfratello and Sembenelli (2002) provide evidence of a productivity advantage stemming from foreign ownership, but only in the case of subsidiaries of US multinationals. Conyon et al. (2002), however, find a 14 percent differential in labor productivity between foreign and domestically owned firms in the UK, which can be attributed to differences in ownership per se. Surveying the empirical literature, Barba Navaretti et al. (2004, Chapter 7.3) stress that much of the available empirical evidence "supports a statistical association between foreign ownership and productivity, but not a causal link." They further report that in those studies where a more careful analysis of causality was conducted "differences in productivity between the two groups of firms are smaller than in earlier estimations and often insignificant."

${ }^{2}$ Two notable exception are Djankov and Hoekman (2000) and Evenett and Voicu (2002). Both studies consider only publicly listed companies in the Czech Republic.

${ }^{3}$ There is a large literature focusing on knowledge spillovers from FDI. For a review of the literature on intra-industry spillovers see Görg and Strobl (2001) and Saggi (2002), for evidence on inter-industry spillovers see Javorcik (2004).

${ }^{4}$ This prediction has found empirical support in the context of Germany (Arnold and Hussinger 2005a) and Ireland (Girma, Görg and Strobl 2004).
} 
Third, the evidence based on stock market data suggests that when firms from developed countries acquire firms in emerging markets, the stock market anticipates significant value creation and substantial gains for shareholders of both acquirer and target firms (Chari et al. 2004).

Disentangling correlation and causality is not straightforward. If high productivity plants are chosen by foreign investors, the ownership status becomes endogenous and a simple least-squares estimation invalid. This is why we use propensity score matching to assess the causal effect of foreign ownership on plant productivity. The matching technique creates the missing counterfactual of an acquired plant had it remained under domestic ownership. It does so by pairing up each plant that will receive FDI in the future with a domestic plant with very similar observable characteristics operating in the same sector and year. Propensity score matching is then combined with a difference-in-differences approach. The causal effect of foreign ownership is hence inferred from the average divergence in the productivity growth paths between each acquired plant and its matched control plant, starting from the pre-acquisition year. This strategy allows us to control for observable and unobservable but constant differences between the acquired and the control plants. While this approach has been widely used in labor economics it has not been applied to the estimation of host country effects of FDI.

Employing this novel strategy has several advantages. First, unlike studies using the Heckman (1979) two-step procedure, we do not require a variable that influences the probability of receiving FDI but not the subsequent plant performance. Finding a suitable measure is frequently close to impossible. Second, in contrast to the GMM approach, our strategy does not require multiple lags of variables of interest and avoids questions about the appropriateness of lags as instruments. Besides, it is not dependent on the lack of the second-order correlation in the data. Third, it allows us to follow the performance trajectory of FDI recipients rather than just estimating the average effect of receiving FDI. Finally, we are able to trace changes in other aspects of plant operations, such as investment, employment and exporting without having to model them explicitly.

Our analysis, based on the plant-level data from the Census of Indonesian Manufacturing Plants covering the period 1983-96, shows that foreign ownership has a significant positive effect on plant performance measured in terms of total factor productivity (TFP). TFP is estimated at the level of 4-digit sectors using the Levinsohn-Petrin (2003) procedure to correct for simultaneity between productivity shocks and input choices. The estimated increase in plant productivity is quite large, reaching about 34 percent in the third year of foreign ownership. About half of the positive productivity effect is realized during the year foreign investment takes place with the rest occurring during the following two years. While this effect is larger than the 14 percent differential found in the UK by Conyon et al. (2002), it is 
smaller than the 43 percent advantage obtained for the Czech Republic by Evenett and Voicu (2003). As the productivity gap between domestic plants and multinational companies is most likely considerably larger in a developing country than in the UK, finding a bigger effect in a developing country context is not surprising.

Several robustness checks are performed to assess the validity of the findings. First, we show that the results are robust to extending the time horizon under consideration to five years of foreign ownership. This exercise indicates that receiving FDI leads not only to an immediate boost to productivity but that the improvements continue to take place in subsequent periods. Second, to eliminate the possibility that pre-acquistion trends in productivity may be influencing our findings, we demonstrate that the results hold when matching takes into account the rate of productivity change in the period prior to acquisition. Third, our results are not affected when we relax the restriction of matching within the same sector and year.

Additionally, we provide evidence indicating that productivity improvements take place simultaneously with increases in investment outlays, employment, wages and output, thus suggesting an on-going restructuring process. We also demonstrate that plants receiving foreign investment become more integrated into the global economy by exporting a larger share of their output and sourcing a larger share of their inputs from abroad.

Our results, pointing to profound changes taking place in FDI recipients, are consistent with anecdotal evidence. For instance, when the German company Caatoosee AG acquired an Indonesian software firm, Sigma, the employment in the acquired firm increased by 20 percent within just twelve months. ${ }^{5}$ Two years later, AlphaBITS, the software developed by Sigma received Merit Award for the best industrial application at the Asia Pacific ICT Award 2001. It was the first time ever Indonesia participated in the event attended by competitors from 11 countries. $^{6}$ Similarly, when H.J. Heinz purchased a majority stake in PT ABC Central Food Industry, maker of Indonesia's hot chili sauce and the world's second largest producer of soy sauce, it did so with an intention to transform the Indonesian plant into a launch pad for an ethnic foods business worldwide. ${ }^{7}$ The steel industry provides an example of technology transfer from abroad to an Indonesian subsidiary. The Maspion Stainless Steel Indonesia, a joint venture between Indonesia's PT Alumindo and Kanematsu Corp of Japan, is on the way to become the first stainless steel cold rolling mill in Indonesia to produce stainless steel coil and sheet of grades

\footnotetext{
${ }^{5}$ http://www.hv-info.de/download/Caatoosee_02-03-31_GB.pdf

${ }^{6}$ http://www.sigma.co.id/history.asp

7 Source: "U.S. Firms See Hope Amid Woe in Indonesia-A Hardy Few Brave Riots to Make Acquisitions; Ford, Citygroup Wade In" The Wall Street Journal, June 1, 1999, A16.
} 
SUS 304 and 43 thanks to the technology provided by Sumitomo Metals of Japan under the technical assistance agreement. ${ }^{8}$

While we have confidence in our results, we also address the plausibility of alternative explanations that could be consistent with the observed pattern. First, we eliminate the possibility that the observed improvements are purely driven by a valuation effect by pointing out that the productivity improvement is not a level effect but a gradual process taking place over a longer period of time. Moreover, as there is no difference between the acquired plants and the control group in terms of royalty payments, our productivity results cannot be attributed exclusively to an introduction of new brand names. We also demonstrate that productivity improvements are present in plants that are not engaged in exporting, importing and do not make royalty payments, which suggests that our findings are not driven by accounting differences related to international transactions motivated by transfer pricing.

Second, to address the concern that the benefit of foreign ownership might be limited to easing credit constraints, our matching procedure includes a binary variable indicating the use of bank loans. Furthermore, our conclusions do not change when matching is performed using a Mahalanobis distance measure that includes the value of investment undertaken during the year when foreign investment is received, thus eliminating differences in contemporaneous investment between the treatment and the control group.

Third, our findings are unlikely to be due solely to scale economies. The production functions estimated at the sectoral level indicate that in 77 percent of sectors constant returns to scale cannot be rejected. We also show that foreign ownership is not associated with an increase in capacity utilization. Fourth, we demonstrate that our results cannot be explained by improvements undertaken in preparation for entering foreign markets, as they hold even for the subsample of non-exporting plants.

Fifth, to support our conclusion that it is foreign ownership per se rather than mergers and acquisitions in general that leads to an improved performance, we use propensity score matching combined with a difference-in-differences approach to compare productivity outcomes for privatizations into domestic and foreign hands. We show that transfer of public ownership to foreign investors is associated with greater productivity improvements than domestic privatizations. Additionally, we utilize data on several domestic acquisitions from the Securities Data Corporation Mergers and Acquisitions Database to show that in contrast to foreign acquisitions, domestic M\&As are not associated with an increase in cost efficiency.

\footnotetext{
${ }^{8}$ Source: http://www.alumindo.com/subsidiary.html
} 
Finally, by confirming our findings using the Generalized Method of Moments (GMM) we eliminate the possibility that our choice of econometric strategy is crucial to our findings.

To summarize, while there is some indication that better performers become FDI recipients, foreign ownership per se is found to lead to an improved performance of acquired plants. Thus we conclude that FDI has a positive direct effect on the productivity of recipient plants in the host country. This finding confirms an implicit assumption made in the literature on FDI spillovers and indicates that FDI indeed presents a potential for knowledge transfer through spillover effects.

The remainder of the paper is structured as follows. The next section reviews the existing literature. Section 3 outlines our empirical strategy for identifying the causal relationship. Section 4 describes the Indonesian Census of Manufacturing. Section 5 provides evidence suggesting that plants receiving FDI exhibit superior performance several years before the change in ownership takes place. Section 6 explains the details of propensity score matching and the difference-in-differences technique used. Section 7 presents the results of this analysis, while Section 8 focuses on robustness checks. The last section concludes.

\section{Existing Literature}

Multinational companies compensate for disadvantages of operating in foreign and unfamiliar markets through their large endowments of intangible assets, such as, superior technologies, patents, trade secrets, know-how, brand names, management techniques and marketing strategies (Dunning 1993). Indeed the existing empirical literature has shown that firms undertaking FDI are characterized by high levels of $\mathrm{R} \& \mathrm{D}$ relative to sales, a large share of professional and technical workers in total employment, new and/or technically complex products and high levels of product differentiation and advertising (Markusen 1995). It has also been demonstrated that multinational companies tend to invest more in labor training than local firms in host countries. ${ }^{9}$ A significant portion of outlays on employee training is associated with technology transfer from the parent company to its foreign subsidiaries. It is not uncommon for staff from headquarters to conduct training in subsidiaries or for subsidiary staff to be trained at headquarters. ${ }^{10}$ The combination of large

\footnotetext{
${ }^{9}$ For instance, according to the survey described by Kertesi and Köllö (2001), foreign-owned firms in Hungary spent 14.2 percent of their investment on training, as compared to 2.4 percent in the case of domestic firms. Similarly, Filer et al. (1995) found that in foreign-owned firms in the Czech Republic spent 4.6 times more than domestic firms on hiring and training. A recent study focusing on Malaysia also showed that foreign-owned firms provide more training to their workers than domestic enterprises (World Bank 1997).

${ }^{10}$ Ramachandaram (1993) shows that as a result of a licensing agreement for technology transfer to a subsidiary, foreign parent companies sent on average 2.46 employees from the headquarters to their
} 
endowment of intangible assets and high investment in staff training suggests that a change from domestic to foreign ownership is likely to lead to improvements in the plant's operations through better production technologies and management techniques.

Performance comparisons between foreign and domestic plants face a number of econometric challenges. First, plants acquired by foreign investors are unlikely to be a random sample from the population. To the extent that the acquisition targets differ systematically from other plants, a problem of simultaneity between ownership status and other performance-relevant variables will arise and bias the estimate of the productivity advantage. Second, partial measures of productivity (such as output per worker) cannot provide a reliable picture because of possible systematic differences in production technologies. ${ }^{11}$ Third, the measurement of total factor productivity itself is prone to errors. As plants choose their factor compositions, they may take into account productivity shocks that are unobservable in the data. If productivity and inputs are determined simultaneously, as is most likely the case, the results of least squares productivity estimations are biased.

The related literature can be classified according to the extent to which it takes into account the three problems mentioned above. A number of studies restrict their attention to measuring labor productivity using value added per worker. Evidence of a positive correlation of this measure with foreign ownership has been presented by Haddad and Harrison (1993) for Morocco, Griffith and Simpson (2001) for the UK and Girma et al. (2004) for Ireland. Total factor productivity has been compared against the nationality of ownership by Aitken and Harrison (1999) in Venezuela, Djankov and Hoekman (2000) and Evenett and Voicu (2003) in the Czech Republic, Doms and Jensen (1998) in the United States, Griffith (1999) and Harris (2002) in the British car industry and by Benfratello and Sembenelli (2002) in Italy. These studies find a positive relationship between foreign ownership and TFP, but the magnitude of the difference between domestic and foreign establishments tends to be much smaller than the effects on partial productivity measures in other studies. The latter three papers control for the endogeneity of input choice by instrumenting explanatory variables with their lagged values, using a GMM estimator suggested by Arellano and Bond (1991). Benfratello and Sembenelli (2002) also exploit this estimator to control for the endogeneity of ownership by taking into account changes in ownership within plants. Evenett and Voicu (2003) correct for the selection bias using Heckman's two-step model and correct for the simultaneity between input choice and productivity using the Olley-Pakes (1996) procedure.

fully-owned subsidiaries in India and 1.91 subsidiary employees visited the headquarters for training. For partially-owned foreign projects, the corresponding figures were 0.65 and 0.61 .

11 Griffith and Simpson (2001) provide evidence that foreign firms in the UK use production technologies that are consistently more intensive in capital and skills than those used by domestic firms. 
Benfratello and Sembenelli (2002) and Evenett and Voicu (2003) are the only studies addressing all three empirical problems outlined above. The former study finds that foreign ownership has no effect on productivity, while the latter documents a positive relationship. ${ }^{12}$ The divergence of methods and results suggests that the empirical specification may strongly influence the conclusions on whether or not foreign ownership per se is associated with productivity advantages.

\section{Empirical Strategy}

The first part of our strategy to address the endogeneity of ownership status is to focus on changes from domestic to foreign ownership taking place within the same plant. Naturally, this approach implies a substantial reduction of the number of plants considered. However, a nice feature of our data is that the sample size is large enough that we are still left with a sufficient number of observations to generalize our results with confidence. The advantage of focusing on plants observed before and after an ownership change is that through a difference-in-differences approach we can control for all non-random elements of the acquisition decision that are constant or strongly persistent over time.

Using a difference-in-differences technique allows us to compare the performance of acquired plants with the performance of plants remaining in domestic hands. This comparison, however, is still vulnerable to problems of non-random sample selection. To address the selection issue, we combine a difference-in-differences approach with propensity score matching. ${ }^{13}$ The matching procedure controls for the selection bias by restricting the comparison to differences within carefully selected pairs of plants. Each pair consists of an acquired plant and a domestic plant with similar observable characteristics in the year preceding the acquisition of the former.

The aim of the analysis is to estimate the causal effect of foreign ownership on total factor productivity growth, defined as

$$
\mathrm{E}\left(\mathrm{Y}_{1}-\left.\mathrm{Y}_{0}\right|_{\mathrm{FDI}=1}\right)=\mathrm{E}\left(\left.\mathrm{Y}_{1}\right|_{\mathrm{FDI}=1}\right)-\mathrm{E}\left(\left.\mathrm{Y}_{0}\right|_{\mathrm{FDI}=1}\right)
$$

\footnotetext{
12 Conyon et al. (2002) consider foreign acquisitions in the UK and employ the GMM estimator to correct for the selection of acquisition targets. However, as their variable of interest is value added per worker, they do not address the simultaneity of input choice. Their results suggest that foreign ownership improves productivity, but it is not significant in all specifications except for subsidiaries of US multinationals. Girma and Görg (2003) also look at foreign acquisitions and find mixed effects on TFP depending on the sector they analyze, but they use a measure of TFP that does not take into account the simultaneity problem of input choices.

13 Apart from its original applications in labor economics, the matching estimator has become increasingly popular in causal analyses in other areas of economics. Girma et al. (2004) and Arnold and Hussinger (2005b) apply this technique to examine the relationship between firm productivity and exporting. Barba Navaretti and Castellani (2004) also use this technique to examine the impact of outward FDI on home performance for a sample of Italian firms.
} 
which is the difference between the performance paths of plants that changed ownership (first term) and the analogous outcome of the same plants had they not been acquired by foreign investors (second term). ${ }^{14}$ The latter outcome is, however, an unobserved counterfactual. The matching technique is a way of constructing this missing counterfactual by drawing comparisons conditional on a vector $\mathrm{X}$ of observable plant characteristics. The underlying assumption for the validity of the procedure is that conditional on the observable characteristics that are relevant for the acquisition decision, the treated (FDI recipients) and non-treated plants (those remaining in domestic hands) would exhibit a similar performance under the same circumstances:

$$
\mathrm{E}\left(\mathrm{Y}_{1}-\left.\mathrm{Y}_{0}\right|_{\mathrm{FDI}=1, \mathrm{X}}\right)=\left(\mathrm{E}\left(\left.\mathrm{Y}_{1}\right|_{\mathrm{FDI}=1, \mathrm{X}}\right)-\mathrm{E}\left(\left.\mathrm{Y}_{0}\right|_{\mathrm{FDI}=0, \mathrm{X}}\right)\right)-\left(\mathrm{E}\left(\left.\mathrm{Y}_{0}\right|_{\mathrm{FDI}=1, \mathrm{X}}\right)-\mathrm{E}\left(\left.\mathrm{Y}_{0}\right|_{\mathrm{FDI}=0, \mathrm{X}}\right)\right)
$$

The second difference in equation 2 is the selection bias, which is assumed to be zero conditional on X. It represents the difference between the outcome of the acquired plants, under the hypothetical circumstances that they had they not been acquired, and those plants that remained in domestic hands, in the same (and this time true) situation of no ownership change. If the selection bias represented by the second term is zero for given realizations of the vector $\mathrm{X}$, then we are left with only the causal effect. In other words, the performance difference between acquired plants and the carefully selected group of control observations is a consistent estimate of the causal effect under the matching assumption. Hence, if our matching process is successful, we can give a causal interpretation to the average performance difference between treatment and control plants.

Conditioning on a vector of variables is difficult, since it requires weighting differences in one dimension against another. Rosenbaum and Rubin (1983) provide a proof that conditioning on the propensity score is equivalent to conditioning on all variables in the treatment model. The propensity score is the predicted probability of treatment, which in our case is the probability of a plant receiving FDI. Making use of this result, we employ propensity score matching and compare the performance of plants within the pairs of observations matched on the propensity score. We also make sure that the matched control observations are assigned only from the same year and the same sector as the acquired plant. This eliminates the possibility that productivity differences across sector/year combinations exert influence on our estimated effects and shifts the focus of attention on the position of each plant with respect to the performance of others in the same sector and year.

\footnotetext{
${ }^{14}$ Our notation is to be read as follows: The outcome variable Y represents productivity growth across the ownership change of the acquired (treatment) plants. Its subscript describes the (potentially hypothetical) circumstances under which an outcome is observed, while FDI $=1$ indicates reference to the group of firms that have been acquired in reality, i.e. our treatment group. Similarly, FDI=0 refers to control observations.
} 
The combination of matching and a difference-in-differences approach means that we look for divergence in the paths of performance between the acquired plants and the matched control plants that had similar characteristics in the pre-acquisition year. The performance analysis begins in the pre-acquisition period and focuses on the (cumulative) change in performance over the following year and then each of the subsequent two periods. Blundell and Costa Dias (2000) emphasize the benefits of combining matching and a difference-in-differences approach for controlling for observable and unobservable but constant differences between treatment and control units. While matching accounts for differences in observable characteristics, its combination with difference-in-differences analysis provides "scope for an unobserved determinant of participation as long as it can be represented by separable individual- and/or time-specific components of the error term." Examples of such determinants include a particular plant being chosen as an acquisition target because of the qualities of its manager or a foreign investor's preference for a plant possessing particular tangible assets (e.g., a distribution network) or intangible assets (an established brand name).

As the performance measure, we employ total factor productivity, defined as the residual of a Cobb-Douglas production function. We address the simultaneity problem in input choices by applying a semi-parametric estimator proposed by Levinsohn and Petrin (2003) with intermediate input use serving as a proxy for productivity shocks. More specifically, we utilize information the amount of electricity consumed by each plant. As electricity cannot be stored, its consumption is likely to follow changes in production activity more closely than the use of materials.

\section{Data}

Indonesia is a suitable choice for studying the effects of FDI. The country's industrial success is a relatively recent phenomenon, and there have been significant inflows of foreign direct investment in the last two decades. In terms of GDP, the importance of foreign direct investment inflows has been rising steadily and significantly from the mid-1980s onwards, as can be seen from Figure A1. For the period 1990-1996, the country was the fifth largest developing country recipient of FDI (IFC 1997, p.17).

Historically, the Indonesian manufacturing sector (excluding oil-related activities) has been of almost negligible importance until the 1970s, accounting for less than 10 percent of GDP in 1974-76. Only in the 1980s did the country begin to emerge as a significant industrial power. The attitude towards foreign direct investment has been generally welcoming since the late 1960s. However, as economic policy began to 
reduce trade barriers and deregulate industry in the early 1980s, Indonesia received a new surge in FDI inflows that tended to be geared towards efficient and internationally competitive activities, mainly in the manufacturing sector (Hill, 2000, p.76). This coincides with the beginning of our data window.

The data used in this paper come from the "Survei Manufaktur," the Indonesian Census of Manufacturing, which has been conducted by the National Statistical Office (BPS) on annual basis since 1975. The census surveys all registered manufacturing plants with more than 20 employees. ${ }^{15}$ It contains detailed information on a large number of variables pertaining to input and output flows. There is some variation on the availability of variables from year to year, and the information of interest to us is available from as early as 1983. As the last year of our sample, we include 1996 in order to avoid capturing the effects of the Asian financial crisis, which strongly affected Indonesia beginning in 1997. In particular, we are concerned about a decline in the data quality due to the crisis and about a change in the motivation for foreign acquisitions in times when many Indonesian plants found themselves in financial distress. Our sample, covering the period 1983 1996, contains more than 210,000 plant observations, of which about 5 percent belong to foreign-owned plants. The average spell a plant remains in our sample is between 8 and 9 years. $^{16}$

In order to estimate the production function, we make use of the information on output (net of energy costs) and four factors of production: the number of production and non-production workers, materials and capital. The capital stock variable has been newly constructed using the perpetual inventory method, making use of detailed data on investment in land, buildings, machinery, vehicles and other fixed assets. ${ }^{17}$ To each investment data series (land, buildings, etc.) we applied estimated depreciation rates from Harris et al. (1994). ${ }^{18}$

\footnotetext{
15 Since regional statistical offices in Indonesia have financial incentives to obtain the relevant information from all active firms, we can be reasonably confident that the entire manufacturing sector above the 20 employee threshold is included in our sample. The survey questionnaires can be accessed online at http://www.rand.org/labor/bps.data/webdocs/statistik_industri/si_main.htm.

${ }^{16}$ The data have been cleaned conservatively for obvious keypunch errors. Particularly for the share of foreign ownership, we replaced outlier values with adjacent values whenever there was a drop to zero followed by a return to the previous value (e.g. 58, 58, 0, 58), or a different position of the decimal point followed by a return to the previous value (as in $60,6,60,60$ ) .

17 We used the earliest available information on self-reported replacement values of each capital category as an anchor for the perpetual inventory method. Where a plant did not report the replacement values of its assets, we used the self-reported book values instead. Plants that never report capital stocks were dropped from our sample. Since the investment question was not asked in 1996, we had to use linear interpolation on the basis of real investment figures in the two surrounding years for that year.

${ }^{18}$ The assumed annual depreciation rate for buildings is 3.3 percent, for machinery 10 percent, and for vehicles and other fixed assets 20 percent. For land, we assumed no depreciation. These rates are very similar to estimates presented in Goeltom (1995).
} 
Since the data contain no information on physical quantities of inputs used or output produced by plants, we are forced to start with nominal values instead. These are deflated using a set of 192 wholesale price indices for manufactured commodities, published by the Indonesian Statistical Office. The commodity indices are mapped to the 5-digit ISIC classification using a concordance table provided by the Statistical Office. These detailed 5-digit ISIC level deflators are applied to plant output and material inputs. Figures on investment and capital are deflated as follows. For buildings, we use a wholesale price index (WPI) published in the Statistical Yearbook of Indonesia, and for machinery and vehicles the average of the WPIs for 5-digit sectors producing machinery and vehicles, respectively. For other assets, we employ the economy-wide WPI. Unfortunately, the Indonesian Statistical Office does not publish a wholesale price index for energy, so we were constrained to use a CPI specific to energy instead.

The production function is assumed to be Cobb-Douglas and is estimated using the semiparametric procedure suggested by Levinsohn and Petrin (2003). ${ }^{19}$ As a proxy for unobserved productivity shocks that may influence the input decision of the plant, we employ the amount of electricity consumed by each plant. The data contain information on electricity consumption net of own production and sales to other plants, expressed in physical quantities $(\mathrm{kWh})$ which rules out measurement errors related to deflation. Our productivity measure is the residual of the production function in logarithmic form. We allow the coefficient estimates to differ over 62 manufacturing sectors, which is equivalent to the 4 -digit ISIC level. ${ }^{20}$ Given a substantial number of missing values in our data set, we are able to estimate TFP for about 120,000 plant observations. To avoid capturing effects caused by a change in principal activity of the plant, our matching analysis focuses only on plants that do not switch their sector of operation. ${ }^{21}$

We perform our analysis on 185 plants that switched from domestic to foreign ownership and remain in the data sufficiently long to be observed in the year before the acquisition, the acquisition period and two subsequent years. ${ }^{22}$ This is a

\footnotetext{
${ }^{19}$ The estimation was implemented in Stata 8 using the program described in Levinsohn et al. (2003). In 29 out of 62 industries this procedure moved the coefficient on capital in the expected upward direction when compared to a fixed effects estimation of the production function. This makes us feel confident that the correction is performing sufficiently well.

${ }^{20}$ The industry breakdown was adjusted to eliminate inconsistencies caused by the fact that BPS had removed several sectors and introduced a few others into the classification during the period of interest. In such cases, plants were regrouped into the corresponding ISIC Rev. 2 industries. Two petroleum sectors (ISIC 3530 and 3540) were dropped from the sample because of a very small number of observations. ISIC sectors 3901-3909 (Manufacturing industries not elsewhere classified) were also dropped due to concerns about plant heterogeneity within these sectors.

${ }^{21}$ Recall the we assign matches within the same sector and year to assure comparability. Considering plants that switch from one sector to another would make it impossible to maintain this matching restriction.

${ }^{22}$ We consider all plants with a foreign capital share above 20 percent as foreign owned. In practice, however, the exact value of this threshold does not matter because in more than 95 percent of
} 
considerable number, considering that Conyon et al. (2000) find only 129 cases of foreign acquisitions with enough non-missing data to make them suitable for their analysis. Their study analyzes a large developed country (the UK) and covers almost the same time period (1987-96). In a UK data set covering the period from 1980 to 1994, Girma and Görg (2003) are able to identify only 266 foreign acquisitions. Figures A3 and A4 show the distribution of acquired plants in our data across years and sectors, respectively. Ownership changes occur in each 2-digit sector and in each year during the 1984-94 period. $^{23}$

\section{Evidence of the Selection Bias}

Our empirical strategy is driven by our concern about the selection bias that may result from better performing plants being acquired by foreign investors. To examine whether this concern is justified, we regress total factor productivity on a dummy for plants with foreign ownership in year $t$ and a dummy for future acquisition targets during the three years prior to the ownership change. ${ }^{24}$ The model also includes industry, region and year fixed effects. We exclude plants with foreign ownership throughout the period.

The estimation results, presented in Table 1, demonstrate that future acquisition targets of foreign investors outperform other Indonesian plants during the three years preceding the ownership change. Not surprisingly, we also find that plants with foreign ownership exhibit a higher productivity than domestic plants. The magnitude of the effect is equal to 19.5 percent for future acquisition targets and 39 percent for plants with foreign ownership.

We interpret this finding as indicating that foreign investors acquire domestic plants with an above average performance, a pattern sometimes called "cherry picking" in the literature. The evidence is strong enough to make a strategy of simply ignoring the issue imprudent. Therefore, in our analysis of the causal effect of foreign ownership on the plant performance, we will control for the selection bias. At the same time, the productivity premium exhibited by plants under foreign ownership is more than twice as large as the premium exhibited before receiving FDI, suggesting that foreign ownership may also have a positive effect on plant performance. In the next section, we analyze this relationship in more detail.

acquisition cases the foreign capital share increased from 0 to 25 or more percent. Figure A2 depicts the distribution of foreign ownership share in the year following the entry of a foreign investor.

${ }^{23}$ Note that we do not consider changes in ownership taking place after 1994 as we want to observe each plant for at least two years after such a change has taken place.

${ }^{24}$ For example, in the case of a firm that receives FDI in 1993, the dummy would take on the value of one for 1990, 1991 and 1992 and zero for all other years. 
Table 1. Evidence of the Selection Bias

\begin{tabular}{lc} 
Dependent Variable is Log TFP & Premium \\
\hline \hline Plant will receive FDI within next 3 years & $\begin{array}{c}0.178^{* * *} \\
(0.022)\end{array}$ \\
& $0.331^{* * *}$ \\
Foreign Ownership & $(0.009)$ \\
& 111,707 \\
No. of observations & \\
& \\
\hline The regression includes industry, year and region fixed effects. \\
Plants under foreign ownership throughout the period are excluded from the sample. \\
$*, * *, * * *$ indicate statistical significance at the 10, 5 and $1 \%$ level, respectively.
\end{tabular}

\section{Controlling for the Sample Selection Using the Matching Technique}

In order to make a meaningful comparison between the performance of Indonesian plants acquired by foreign investors and those remaining in domestic hands, we need to create a missing counterfactual capturing the performance of the acquired plants had they not received FDI. We do so by applying a matching technique to identify a suitable plant under continued domestic ownership to which we can compare each acquired plant. The requirement for a suitable control observation is sufficient similarity to the future acquisition target with respect to key determinants of the acquisition decision, so as to make these two plants a priori equally probable targets of a potential foreign acquisition.

For obvious reasons, the control group is created on basis of observable plant characteristics. We believe that this is a good starting point as potential foreign investors rely heavily on basic observable characteristics of plants, such as their age, size, employment composition, machinery and equipment available, productivity, etc. to narrow down the number of potential acquisition targets. They may also judge suitability of plants based on their reliance on imported inputs which may indicate the sophistication level of the technology used. Finally, the fact that an establishment has received a bank loan may also contain information on financial institutions' perceptions about trustworthiness and future prospects of an establishment. All of these factors are taken into account when constructing the control group.

We use one-to-one nearest neighbor matching on the propensity score, which expresses the estimated probability of a plant becoming acquired by a foreign investor. ${ }^{25}$ As mentioned in Section 3, this solves the dimensionality problem when considering differences on more than one observable characteristic. Moreover, we

\footnotetext{
${ }^{25}$ We also tried other matching methods, such as kernel matching and caliper matching, and the results were qualitatively similar.
} 
impose the additional requirement that the matched plant observations come from the same sector and year. ${ }^{26}$ Therefore, in a first step, we use a probit regression to model the binary outcome of a plant becoming acquired by foreigners on the basis of plant-specific characteristics. To avoid endogeneity, all explanatory variables (except for age) are lagged one year. ${ }^{27}$

The results from the probit regression, presented in Table 2, indicate that plants acquired by foreign investors differ systematically from other domestic plants. The model suggests that younger and larger (in terms of employment) plants are more likely to become acquired. The model allows for nonlinear effects of these two variables which indeed appear to be statistically significant. Further, the data show that plants with higher capital-labor ratio, plants engaged in sourcing inputs from abroad and plants with a higher fraction of white-collar employees tend to be more attractive to foreign investors. As the goal of the study is to examine improvements in productivity due to the change in ownership, the model includes controls for the TFP level (normalized by the average TFP observed in the same industry and year) in the period prior to receiving FDI. This variable does not appear to be statistically significant, which is most likely due to a high correlation with other controls. Recall, however, that the results presented in the previous section suggest that the acquired plants exhibit superior performance already three years before the acquisition.

To eliminate the possibility that improvements observed after the ownership change may be due to investments undertaken by plants prior to or in preparation for a foreign acquisition, the matching procedure controls for investment outlays lagged one period. This variable, however, does not appear to be statistically significant. To attenuate the possibility that the effect of FDI works purely through easing access to credit, the probit model also includes a dummy for plants having a bank loan but again the coefficient does not reach conventional significance levels. Finally, the model includes a dummy for plants with public ownership and a time trend, neither of which are statistically significant.

To assess how well the propensity score matching performs in our case, we calculate the difference between the treated and the control group in terms of each of the above variables and run simple t-tests on the differences within 8 bands of the propensity score. This test is called the balancing hypothesis, and it can be performed using the procedure suggested by Becker and Ichino (2002). All of the differences are found to be small and statistically insignificant. This gives us

\footnotetext{
${ }^{26}$ Our matching procedure is implemented in Stata 8 using a modified version of the procedure described in Leuven and Sianesi (2001). The modifications were necessary to make sure that matched pairs come from the same year and sector.

${ }^{27}$ In order to increase the precision of our model, we dropped all combinations of sectors, years and regions where no foreign acquisitions occurred. Not making this adjustment would increase the number of observations in Table 2 to 57,607 but would not change the conclusions of the paper.
} 
confidence that our approach is capable of grouping together relatively homogeneous plants. $^{28}$

Table 2. Probit results

Dependent Variable: Foreign acquisition

\begin{tabular}{ll}
\hline \hline ln Employment & $0.813^{* * *}$ \\
& $(0.246)$ \\
ln Employment ${ }^{2}$ & $-0.069^{* * *}$ \\
& $(0.023)$ \\
Age & $-0.051^{* * *}$ \\
& $(0.008)$ \\
Age $^{2}$ & $0.0006^{* * *}$ \\
& $(0.0001)$ \\
ln Capital intensity & $0.084^{* * *}$ \\
& $(0.201)$ \\
Share of imported inputs & $0.650^{* * *}$ \\
& $(0.102)$ \\
Ratio of non-production workers & $1.170^{* * *}$ \\
& $(0.243)$ \\
ln Relative TFP & 0.059 \\
& $(0.076)$ \\
ln Investment & -0.003 \\
& $(0.010)$ \\
Bank loan dummy & 0.0003 \\
& $(0.0003)$ \\
Public ownership dummy & 0.110 \\
Time trend & $(0.157)$ \\
& 0.026 \\
Intercept & $(0.016)$ \\
& $-4.042^{* * *}$ \\
No. of obs. & $(0.645)$ \\
Chi ${ }^{2}$ & 2,355 \\
Prob $>$ Chi ${ }^{2}$ & 186.01 \\
Pseudo R & \\
\hline \hline All explanatory variables with the exception of age & and age ${ }^{2}$ are \\
lagged one year. & \\
level, respectively & 0.00 \\
& 0.11 \\
& and $1 \%$ \\
& \\
& \\
& \\
&
\end{tabular}

The predicted probabilities are used to assign to each future acquisition target a domestic plant that has the closest propensity score within the same year and sector. Thanks to a large number of available control observations in our data, the matching procedure produces an average distance in propensity scores within matched pairs of less than 4 percent, with a standard variation of approximately 5 percent. This convinces us that our matching procedure has managed to find appropriate comparison observations for each acquired plant.

\footnotetext{
${ }^{28}$ In our matching procedure we also exclude observations outside the common support. The common support is bound by the lowest propensity score of a treatment observation and the highest propensity score of a control observation.
} 


\section{Results from the Difference-in-Differences Analysis on the Matched Sample}

\section{(a) Baseline results}

The primary result of interest is the average difference in TFP in the matched pairs, net of the average initial difference before the acquisition. As can be seen in Table 3, between the year prior to the acquisition, in which the matches are assigned, and the acquisition year, the treatment and control observations diverge significantly in terms of productivity. A foreign acquisition leads to an additional 15-percentagepoint productivity boost in the acquired plants, which is not shared by similar plants remaining in domestic hands. In the subsequent years, the divergence in performance becomes even greater. By the end of the third year of foreign ownership, the acquired plants enjoy a productivity advantage over the control group equivalent to 34 percentage points. The results are significant at the five percent level in the acquisition year and at the one percent level in the following two years.

Table 3. Matching Results for Productivity

\begin{tabular}{|c|c|}
\hline Effect of Foreign Acquisition & Log TFP \\
\hline "Acquisition year $^{(\mathrm{a})}$ & $\begin{array}{l}0.147^{* *} \\
(0.065)\end{array}$ \\
\hline \multirow[t]{2}{*}{ One year later ${ }^{(\mathrm{b})}$} & $0.259^{* * *}$ \\
\hline & $(0.068)$ \\
\hline \multirow[t]{2}{*}{ Two years later ${ }^{(c)}$} & $0.293^{* * *}$ \\
\hline & $(0.074)$ \\
\hline $\mathrm{n}$ & 185 \\
\hline \multicolumn{2}{|c|}{$\begin{array}{l}\text { Average Treatment Effect on the Treated (ATT), bootstrapped standard errors in parentheses. } \\
\mathrm{n}=\text { number of matched acquisitions } \\
*, * *, * * * \text { indicate statistical significance at the } 10,5 \text { and } 1 \% \text { level, respectively. }\end{array}$} \\
\hline \multicolumn{2}{|c|}{ (a) $\mathrm{ATT}=\frac{1}{n} \sum_{1}^{n}\left(\ln \mathrm{TFP}_{\text {acquisition year }}^{\text {treated }}-\ln \mathrm{TFP}_{\text {acquistion year }}^{\text {control }}\right)-\frac{1}{n} \sum_{1}^{n}\left(\ln \mathrm{TFP}_{\text {pre-acquisition year }}^{\text {treated }}-\ln \mathrm{TFP}_{\text {pre-acquisition year }}^{\text {control }}\right)$} \\
\hline \multicolumn{2}{|c|}{ (b) $\mathrm{ATT}=\frac{1}{n} \sum_{1}^{n}\left(\ln \mathrm{TFP}_{\text {acquisition year }+1}^{\text {treated }}-\ln \mathrm{TFP}_{\text {acquisition year }+1}^{\text {control }}\right)-\frac{1}{n} \sum_{1}^{n}\left(\ln \mathrm{TFP}_{\text {pre-acquisition year }}^{\text {treated }}-\ln \mathrm{TFP}_{\text {pre-acquisition year }}^{\text {control }}\right)$} \\
\hline \multicolumn{2}{|c|}{ (c) $\mathrm{ATT}=\frac{1}{n} \sum_{1}^{n}\left(\ln \mathrm{TFP}_{\text {acquisition year }+2}^{\text {treated }}-\ln \mathrm{TFP}_{\text {acquisition year }+2}^{\text {contrl }}\right)-\frac{1}{n} \sum_{1}^{n}\left(\ln \mathrm{TFP}_{\text {pre-acquisition year }}^{\text {treated }}-\ln \mathrm{TFP}_{\text {pre-acquisition year }}^{\text {control }}\right)$} \\
\hline
\end{tabular}

These figures are quite compelling. Performance improvements resulting from foreign acquisitions are likely to be larger in developing countries where the productivity gap between domestic plants and multinational companies is considerably greater. Thus, our result of a 34 percentage-point productivity advantage over a three-year horizon seems plausible when compared to the 14 percent improvement found by Conyon et al. (2002) in the UK. It is also smaller than the 43 percent improvement found by Evenett and Voicu (2003) in the Czech Republic.

\section{(b) Extending the time horizon}

To confirm that the observed productivity improvement is not a temporary phenomenon, we extend the time horizon to cover two more years after the 
acquisition. The difference-in-differences results presented in Table 4 indicate that improvements experienced by acquired plants as a result of a foreign acquisition continue in the third and fourth year after the acquisition. By the end of the fourth year, the productivity gap between the acquired and the control plants widens to 40 percentage points. As extending the time horizon limits the size of the sample, in the remainder of the study we will focus on the time horizon considered originally.

Table 4. Matching Results - Longer Horizon

\begin{tabular}{lcl} 
Effect of Foreign Acquisition & Log TFP & Log TFP \\
\hline \hline Acquisition year & $0.152^{* *}$ & 0.098 \\
& $(0.07)$ & $(0.09)$ \\
One year later & $0.275^{* *}$ & $0.202^{* *}$ \\
& $(0.08)^{* * *}$ & $(0.08)$ \\
Two years later & $0.316^{* *}$ & $0.248^{* *}$ \\
& $(0.11)$ & $(0.11)^{* *}$ \\
Three years later & $0.382^{* * *}$ & $0.354^{* * *}$ \\
& $(0.11)$ & $(0.11)^{* * *}$ \\
Four years later & & $0.327^{* *}$ \\
& & $(0.11)$ \\
\hline $\mathrm{n}$ & 152 & 108 \\
\hline \hline Average Treatment Effect on the Treated. Bootstrapped std errors in parentheses. \\
$*, * *, * * *$ indicate statistical significance at the 10, 5 and $1 \%$ level, respectively.
\end{tabular}

It is worth pointing out that the observed effects of foreign ownership are driven by an improved performance of the acquired plants rather than by a deterioration in the situation of the control group. If we were to compare to the acquired plants to the average performer in the same sector and year (rather than to the control group), the advantage of foreign ownership would appear to be even greater. This suggests that the propensity score matching performs well in constructing a suitable control group.

(c) Removing the restriction on matching within sectors

To ensure that our matching results are not distorted by restricting the control observations to come from the same sector and the same time period, below we present the results obtained without imposing this constraint. As evident from Table 5 , this modification leads to the same qualitative conclusions. Allowing out-of-sector matching, however, produces somewhat smaller effects. The estimated productivity advantage is almost identical regardless of whether the absolute TFP measure or the TFP relative to the industry average in a given year is considered. ${ }^{29}$

\footnotetext{
${ }^{29}$ Note that in this case it makes sense to consider both absolute and relative TFP measures because sectoral averages do not cancel out as the treated and the control observations may belong to different sectors.
} 
Table 5. Matching Results for Productivity, not restricted within sector/year

\begin{tabular}{lll} 
Effect of Foreign Acquisition & Relative TFP & Log TFP \\
\hline \hline Acquisition year & $0.134^{* *}$ & $0.132^{* *}$ \\
& $(0.06)$ & $(0.06)$ \\
One year later & $0.225^{* * *}$ & $0.221^{* * *}$ \\
& $(0.06)$ & $(0.06)$ \\
Two years later & $0.208^{* * *}$ & $0.215^{* * *}$ \\
& $(0.07)$ & $(0.06)$ \\
\hline $\mathrm{N}$ & 213 & 213 \\
\hline \hline Average Treatment Effect on the Treated. Bootstrapped std errors in parentheses. \\
$*, * *, * * *$ indicate statistical significance at the 10, 5 and 1\% level, respectively.
\end{tabular}

(d) Accounting for productivity trends prior to acquisition

The difference-in-differences approach removes plant-specific time-invariant effects, however, unobservable but not time-invariant plant-specific characteristics still may pose a main challenge in the analysis. While in some subfields of development economics this issue is addressed by the use of randomized experiments, this is unfortunately not an option in our context.

As a step toward addressing this issue, we account for pre-acquisition trends in plant performance in the matching stage. We construct a new control group based on a new propensity score including the productivity change in the period preceding the acquisition in addition to the productivity level and all other variables used in Table $2 .^{30}$ This requires one additional observation per plant and thus reduces the sample size. The difference-in-differences approach applied to the newly created matched sample produces no statistically significant divergence between the treated and the control group in the year when FDI is received. A statistically significant difference is found, however, in the first and the second year following the acquisition (see Table 6). Thus this robustness check supports our conclusion that FDI recipients outperform plants remaining in domestic hands.

The effects found in Table 6 are smaller than those obtained earlier, amounting to a 22 percentage-point difference within three years as opposed to a 34-percentagepoint divergence. The difference in magnitudes, however, appears to be driven by the fact that for many acquired plants we do not observe productivity two years before the acquisition and are thus unable to include them in this robustness check. When we reproduce the results of Table 3 restricting the sample to the 99 plants for which such information is available (see column 2 in Table 6), the estimated effects closely resemble those presented in the first column of Table 6.

\footnotetext{
30 The productivity change is calculated as the first difference of $\log$ TFP in the pre-acquisition period while the level refers to the log of TFP relative to the sector/year average in that same year. The latter normalization is done in order to assure comparability (recall that TFP estimates come from regressions performed at the sectoral level). Neither the productivity change nor the productivity level, however, appear to be statistically significant in the probit model.
} 
Table 6. Sample Matched on Lagged TFP Growth

\begin{tabular}{lcc} 
Effect of Foreign Acquisition & $\begin{array}{c}\text { Log TFP } \\
\text { (matched on lagged TFP growth) }\end{array}$ & $\begin{array}{c}\text { Log TFP } \\
\text { (matching corresponding to Table 3) }\end{array}$ \\
\hline \hline Acquisition year & 0.034 & 0.035 \\
& $(0.08)$ & $(0.07)$ \\
One year later & $0.185^{* *}$ & $\left(0.168^{*}\right.$ \\
& $(0.08)$ & $0.181^{*}$ \\
Two years later & $0.201^{* *}$ & $(0.09)$ \\
\hline $\mathrm{n}$ & $(0.10)$ & 99 \\
\hline \hline Average Treatment Effect on the Treated. Bootstrapped std errors in parentheses. & ${ }^{*}$, * $^{*}$, *** $^{*}$ indicate statistical
\end{tabular}

\section{(e) Evidence of restructuring}

If our findings of improved productivity are due to FDI, we would expect to observe foreign owners introduce other changes to plant operations. Indeed we find evidence that acquired plants undergo a restructuring process. As illustrated in Table 7, acquired plants grow much faster between the pre- and the post-acquisition period than the control establishments, implying that foreign ownership helps them increase their output and employment. Further, the acquired plants increase employee wages faster than the control group. ${ }^{31}$ In addition, plants receiving FDI see a larger rise in their investment outlays relative to establishments remaining in domestic hands. All of the mentioned effects are statistically significant throughout the period considered. They are also consistent with the anecdotal evidence mentioned in the introduction.

Table 7. Matching Results for Output, Employment, Wages, Investment

\begin{tabular}{lcccc} 
Effect of Foreign Acquisition & Log Output & Log Employment & Log Wages & Log Investment \\
\hline \hline Acquisition year & $0.665^{* * *}$ & $0.318^{* * *}$ & $0.397^{* * *}$ & $1.561^{* * *}$ \\
& $(0.14)$ & $(0.08)$ & $(0.09)$ & $(0.52)$ \\
One year later & $0.781^{* * *}$ & $0.311^{* * *}$ & $0.382^{* * *}$ & $1.509^{* *}$ \\
& $(0.16)$ & $(0.08)$ & $(0.10)$ & $(0.64)$ \\
Two years later & $0.826^{* * *}$ & $0.331^{* *}$ & $0.407^{* * *}$ & $1.069^{*}$ \\
& $(0.16)$ & $(0.10)$ & $(0.10)$ & $(0.64)$ \\
\hline $\mathrm{n}$ & 185 & 185 & 185 & 185 \\
\hline Average Treatment Effect on the Treated. Bootstrapped std errors in parentheses. & & \\
$*, * *, * * *$ indicate statistical significance at the 10, 5 and 1\% level, respectively. & &
\end{tabular}

The results also indicate that foreign ownership affects participation of the acquired plants in international markets. As illustrated in Table 8, a foreign acquisition leads to an increase the share of output exported by 11 percentage points in the year of acquisition and by an additional 3 percentage points in the following year. ${ }^{32} \mathrm{~A}$

\footnotetext{
${ }^{31}$ This is to be expected as the existing literature has documented that foreign establishments tend to pay higher wages than domestic plants. See Sjoholm and Lipsey (2004) for a careful analysis of the Indonesian case.

${ }^{32}$ This increase in the average export share is a result of both increased export intensity of previously exporting plants and of plants entering foreign markets for the first time after the acquisition. The reduction in the sample size is due to the unavailability of information on exports in the Census data before 1990 .
} 
similar pattern is observed with respect to the reliance on imported inputs. In the acquisition year, treated plants increase the share of imported inputs by 8 percentage points more than the control group. Two years later this difference increases to 12.7 percentage points. Increased reliance on imported intermediates and the ability to enter or expand the presence in foreign markets also suggest that profound changes to the production process may be taking place in the acquired plants.

Table 8. Matching Results for Export Ratio and Ratio of Imported Inputs

\begin{tabular}{llc} 
Effect of Foreign Acquisition & Exports/Sales & $\begin{array}{c}\text { Imported } \\
\text { Inputs/Inputs }\end{array}$ \\
\hline \hline Acquisition year & $11.43^{* *}$ & $8.32^{*}$ \\
& $(5.07)$ & $(3.37)$ \\
One year later & $14.20^{* *}$ & $10.25^{* *}$ \\
& $(5.67)$ & $(4.02)$ \\
Two years later & $14.26^{* *}$ & $12.71^{* * *}$ \\
& $(5.88)$ & $(3.92)$ \\
\hline $\mathrm{n}$ & 133 & 185 \\
\hline \hline Average Treatment Effect on the Treated. Bootstrapped std errors in parentheses. \\
$*, * *, * * *$ indicate statistical significance at the 10, 5 and 1\% level, respectively.
\end{tabular}

To sum up, we observe significant changes in the way that plants are managed once they receive FDI. The foreign acquisition seems to unleash an acquired plant's growth potential both in terms of productivity and size. The improvements materialize quickly and continue over time. Acquisitions also raise investment and wages and intensify the plants' participation in the global economy.

\section{Addressing Alternative Explanations}

As argued earlier, the fact that multinational corporations are characterized by large endowments of intangible assets, high productivity and a willingness to invest in staff training suggests that the observed productivity improvements associated with foreign acquisitions are likely to result from the introduction of new technologies and management techniques and restructuring of plant operations. There exist, however, other explanations which could potentially be consistent with the observed productivity improvements. In this section we explore their plausibility.

(a) Can the results be explained by valuation?

A valuation effect stemming, for instance, from a change in accounting procedures or from an introduction of a brand name, is not a likely explanation for the observed patterns. First, such an effect would lead to a one-time jump in the observed productivity. This is clearly not the case in our sample as we observe a sustained productivity growth over a three-year period. Second, a mere valuation effect would not explain changes in other aspects of plant operations, such as employment, 
participation in the global economy and so on. Third, it is difficult to argue that our findings are purely due to the introduction of a parent company's brand name without any changes being made to the products to which the trademark is then applied. In most cases, the fear of a brand-name erosion would make foreign owners hesitant to apply their trademark to a product unless they are absolutely sure that the company-wide quality standards have been met. Further, royalty payments for the use of the parent company's brand name would be reflected in the company's accounts. Yet, the results from the difference-in-differences approach suggest that the acquired plants do not diverge from the control group in terms of royalty payments made (see Table 9).

Table 9. Matching Results for Royalty Payments

\begin{tabular}{lc} 
Effect of Foreign Acquisition & Royalty Payments \\
\hline \hline Acquisition year & 0.308 \\
& $(0.58)$ \\
One year later & $1.286^{*}$ \\
& $(0.71)$ \\
Two years later & 1.195 \\
& $(0.74)$ \\
\hline $\mathrm{n}$ & 60 \\
\hline \hline Average Treatment Effect on the Treated. Bootstrapped std \\
errors in parentheses. $* * *, * * *$ indicate statistical significance \\
at the 10,5 and $1 \%$ level, respectively.
\end{tabular}

Fourth, while transfer pricing could potentially influence our findings, we believe that this is an unlikely explanation. Accounting statements in Indonesia are prepared according to well-established accounting standards, which are directly based on the U.S. Generally Accepted Accounting Principles (GAAP) (Asian Development Bank 2003, p.97). This suggests that the quality of accounting is reasonably high, particularly in a developing country context. The degree to which transfer pricing motives can introduce measurement errors is limited by these accounting standards. In any event, the incentives for transfer pricing are probably small, because corporate taxes in Indonesia are not much different from those in OECD countries. ${ }^{33}$ Nevertheless, to rule out transfer pricing as the underlying reason for our findings, we limit our sample to acquired plants which do not report any transactions that could be used as a vehicle for transfer pricing (i.e., imports, exports or royalty payments). As reflected in Table 10 below, our earlier conclusions are confirmed even with the restricted sample size. The results suggests that even plants that do not engage in any foreign transactions experience a large and statistically significant productivity improvement (relative to the control group) following a foreign acquisition.

\footnotetext{
33 This conclusion is based on the corporate tax rates reported in the Global Competitiveness Report (1996). The comparison takes into account statutory tax rates as we have no information about tax incentives that may have been granted on a case-by-case basis.
} 
Table 10. Matching Results for Subsample of Plants with no Foreign Transactions

\begin{tabular}{|c|c|c|c|}
\hline Effect of Foreign Acquisition & $\begin{array}{c}\log \text { TFP } \\
\text { (No foreign trade in } t=0 \text { and } \\
t=1 \text { ) }\end{array}$ & $\begin{array}{c}\log \text { TFP } \\
\text { (No foreign trade in } t=0 \text { to } \\
t=2)\end{array}$ & $\begin{array}{l}\text { Log TFP } \\
\text { (No foreign trade and no } \\
\text { royalties in } t=0 \text { to } t=2 \text { ) }\end{array}$ \\
\hline Acquisition year & $\begin{array}{l}0.339^{*} \\
(0.17)\end{array}$ & $\begin{array}{l}0.355^{*} \\
(0.21)\end{array}$ & $\begin{array}{l}0.257 \\
(0.19)\end{array}$ \\
\hline One year later & $\begin{array}{l}0.352^{* *} \\
(0.15)\end{array}$ & $\begin{array}{l}0.323^{*} \\
(0.18)\end{array}$ & $\begin{array}{l}0.216 \\
(0.21)\end{array}$ \\
\hline Two years later & $\begin{array}{l}0.532^{* *} \\
(0.21)\end{array}$ & $\begin{array}{l}0.602^{* *} \\
(0.24)\end{array}$ & $\begin{array}{l}0.553^{* *} \\
(0.26)\end{array}$ \\
\hline $\mathrm{n}$ & 25 & 21 & 16 \\
\hline
\end{tabular}

(b) Could the observed changes be due to foreign acquisitions lessening credit constraints?

While the transfer of know-how and technology accompanied by improvements in management is a plausible explanation for the results presented so far, benefits from foreign ownership could also work through easier access to financing. It is possible that foreign investors pick plants that would have done well in the absence of foreign ownership, had they had sufficient access to credit. For instance, foreigners may choose to invest in local plants that have recently developed a potentially successful new product or identified a promising investment opportunity but are unable to take advantage of it due to lack of financing. If this were the case, the sole impact of foreign investment would be provision of financing rather than transfer of knowledge. To address this possibility we accounted in the construction of the propensity score for having a bank loan as well for investment undertaken by the plant during the year preceding a foreign acquisition (see Table 2). Our matching analysis is thus conditional on these two variables. Neither of the two factors, however, appears to be a statistically significant predictor of a foreign acquisition.

To take this issue even further, we employ an alternative matching technique where we match plants on a Mahalanobis distance measure of the propensity score and the value of investment in the year of ownership change. This allows us to construct a new control group with the following characteristics: (i) similarity to the treament group in terms of observable characteristics (considered earlier) prior to the acquisition, and (ii) similarity in terms of investment undertaken in the year when foreign investment is received. The logic behind this exercise is that if plants from the same industry with similar observable characteristics exhibit a similar investment pattern in the same year, something other than credit constraints should be responsible for a divergence in performance. The results from the difference-indifferences approach applied to this new control group are presented in Table 11. They are very similar to those obtained earlier which suggests that credit constraints are unlikely to be driving our results. 
Table 11. Matching on Mahalanobis Distance including Investment at $\mathrm{t}=0$

\begin{tabular}{lcc} 
Effect of Foreign Acquisition & Log Relative TFP & Log TFP \\
\hline \hline Acquisition year & $0.158^{* * *}$ & $0.168^{* * *}$ \\
One year later & $(0.06)$ & $(0.05)^{* * *}$ \\
& $0.258^{* * *}$ & $0.277^{* * *}$ \\
Two years later & $(0.06)$ & $(0.07)$ \\
& $0.267^{* * *}$ & $0.294^{* * *}$ \\
\hline $\mathrm{n}$ & $(0.08)$ & $(0.07)$ \\
\hline \hline Average Treatment Effect on the Treated. Bootstrapped std errors in parentheses. \\
$*, * *, * * *$ indicate statistical significance at the 10, 5 and 1\% level, respectively.
\end{tabular}

Finally, we check whether the acquired plants experienced a larger increase in the amount of outstanding loans than the control group. This does not appear to be the case. When we consider the value of outstanding loans (both domestic and foreign) normalized by the plant output, and we do not find a statistically significant difference between the two groups (see Table 12). ${ }^{34}$

Table 12. Matching Results for Loans/Sales

\begin{tabular}{lc} 
Effect of Foreign Acquisition & Loans/Sales \\
\hline \hline Acquisition year & -0.055 \\
& $(0.07)$ \\
One year later & -0.042 \\
& $(0.08)$ \\
Two years later & -0.038 \\
& $(0.08)$ \\
\hline $\mathrm{n}$ & 179 \\
\hline \hline Average Treatment Effect on the Treated. Bootstrapped std \\
errors in parentheses. ${ }^{* *},{ }^{* * *}$ indicate statistical significance \\
at the 10,5 and $1 \%$ level, respectively.
\end{tabular}

(c) Can capacity utilization explain the observed productivity improvements?

In order to ascertain whether the changes taking place in the acquired plants are part of a long-term restructuring process, or whether they are short-term expansions of the production scale resulting from the provision of new markets, we also apply the matching analysis to the self-reported information on capacity utilization. As evident from Table 13 below, changes in capacity utilization alone cannot explain the improvements in performance experienced by plants receiving FDI. In the year of acquisition, there is no statistically significant divergence in capacity utilization between the two groups. In the subsequent year, FDI recipients increase their capacity utilization relative to the control group, but two years after the acquisition the difference disappears. Even in the period where the effect is significant at the 10 percent level, however, the average increase in capacity utilization amounts to only 8 percentage points, from 65 to 73 percent.

\footnotetext{
${ }^{34}$ To remove outliers, we drop plants with the loan to output ratio above 10.
} 
Table 13. Matching Results for Capacity Utilization

\begin{tabular}{ll} 
Effect of Foreign Acquisition & $\begin{array}{c}\text { Capacity Utilization } \\
(\%)\end{array}$ \\
\hline \hline Acquisition year & 4.32 \\
& $(4.62)$ \\
One year later & $9.89^{*}$ \\
& $(5.35)$ \\
Two years later & 8.12 \\
& $(5.50)$ \\
\hline $\mathrm{n}$ & 133 \\
\hline \hline Average Treatment Effect on the Treated. Bootstrapped std \\
errors in parentheses. ${ }^{*}, * *, * * *$ indicate statistical significance \\
at the 10, 5 and $1 \%$ level, respectively.
\end{tabular}

Neither are our findings due solely to scale economies. The production functions estimated at the sectoral level indicate that in 77 percent of cases (or 48 out of 62 sectors) constant returns to scale cannot be rejected. Thus, we conclude that the results are consistent with foreign investors inducing deep structural changes in the way the acquired plants are run and cannot be explained by economies of scale. ${ }^{35}$

\section{(d) Are we picking up the exporter effect?}

Our results could potentially reflect the improvements stemming from a plant's effort to prepare for entering export markets, rather than the effect of FDI. To eliminate this possibility, we restrict our attention to the acquired plants that do not export in the acquisition year or the following years. Then we compare the performance of this subsample to the corresponding control plants in the same manner as we did before. This modification results in a very small change to the magnitude of the effect. As before, in all periods considered FDI recipients outperform plants remaining under domestic ownership (see Table 14).

Table 14. Matching Results for the Subsample of Plants with no Exports

\begin{tabular}{ll} 
Effect of Foreign Acquisition & Log TFP \\
\hline \hline Acquisition year & $0.164^{* *}$ \\
& $(0.08)$ \\
One year later & $0.239^{* * *}$ \\
& $(0.08)$ \\
Two years later & $0.295^{* * *}$ \\
& $(0.10)$ \\
\hline $\mathrm{n}$ & 102 \\
\hline \hline Average Treatment Effect on the Treated. Bootstrapped std \\
errors in parentheses. ${ }^{* * *},{ }^{* * *}$ indicate statistical significance \\
at the 10,5 and $1 \%$ level, respectively.
\end{tabular}

(e) Is it foreign ownership per se or acquisitions in general?

While our data set does not allow us to test directly whether the observed productivity improvements stem from foreign ownership per se or would result from any (domestic or foreign) acquisition, we believe that the former explanation is

${ }^{35}$ Little is known about the relationship between plant-level scale economies and multinationality. The available evidence suggests, however, a negative association (see references in Markusen 1995). 
much more plausible for several reasons. First, as explained earlier in the literature review, multinational corporations are characterized by large endowments of intangible assets relative to other firms in developed and, even more so, developing countries. Thus foreign acquisitions present a greater potential for technology and know-how transfer to the acquired plants than domestic takeovers.

Second, domestic M\&A activities in Indonesia were quite limited during the time period considered in our study. According to the Securities Data Corporation Mergers and Acquisitions Database, there were only 47 domestic acquisitions between 1988 (the first year of data availability) and 1994, of which only 19 took place in manufacturing sectors.

Third, as illustrated in the Appendix, the few cases of cases of domestic M\&As in manufacturing, for which data are available, suggest that foreign acquisitions may be associated with greater performance improvements than domestic takeovers. This view is also supported by the evidence from Malaysia presented by Fauzias and Shamsubaridah (1995) who find a statistically significant decline in the performance (measured in terms of earnings per share and return to capital) of establishments acquired by domestic companies.

Further evidence on the differential effect of domestic and foreign acquisitions comes from information on privatization episodes. Our data set does not allow us to identify changes in ownership if both the new and old owners are private Indonesian entities. However, we can observe previously state-owned plants being sold to domestic or foreign owners. We use this fact to compare the performance of formerly state-owned plants that were sold to foreign owners (treatment group) with that of plants sold to domestic interests (control group). Again the difference-in-differences approach is used. To create the control group we model the probability of a stateowned plant being privatized into foreign rather than domestic plants. Privatization is defined as a change leading to the public (central and/or local government) ownership share dropping to less than 20 percent. The explanatory variables in the probit model are the same as those listed in Table 2 with the exception of the public ownership dummy. As illustrated in Table 15 below, we find that previously stateowned plants acquired by foreign investors outperform those sold to domestic interests. The divergence in performance is statistically significant in the first and second year following the privatization. In the second year, the estimated advantage is equal to 35 percentage points which is only one percentage point higher than the effect estimated in our basic specification in Table 3. 
Table 15. Matching Results for Privatization Cases (not restricted within sector/year)

From Public to Foreign Private vs. Domestic Private

Effect of Foreign Acquisition

Log Relative TFP

\begin{tabular}{ll}
\hline \hline Acquisition year & $\begin{array}{l}0.241 \\
(0.16)\end{array}$ \\
One year later & $0.392^{* *}$ \\
& $(0.17)$ \\
& $0.303^{* *}$ \\
Two years later & $(0.146)$ \\
\hline $\mathrm{n}$ & 39 \\
\hline \hline Average Treatment Effect on the Treated. Bootstrapped std \\
errors in parentheses. ${ }^{* *},{ }^{* * *}$ indicate statistical significance \\
at the 10,5 and $1 \%$ level, respectively.
\end{tabular}

(f) Are our results driven by the methodology chosen?

To eliminate the possibility that our results are driven by the methodology chosen, we use an approach employed by several existing studies (Griffith 1999; Harris 2002; Benfratello and Sembenelli 2002). We apply a GMM system estimator, proposed by Blundell and Bond (1999), to estimate a production function including a binary variable for foreign ownership. The production function is estimated separately for 62 industries of the Indonesian manufacturing sector. If foreign ownership has a positive impact on plant productivity, we expect to find a positive coefficient on the FDI variable.

The definitions of variables used in the estimation are the same as those employed earlier, except for the additional FDI dummy. Real output is the dependent variable and the explanatory variables include production labor, non-production labor, materials and capital as well as the FDI dummy. All variables on the right hand side (including FDI) are considered potentially endogenous and are instrumented by levels lagged 3 to 6 periods in the differenced equation and by differences lagged 2 to 6 periods in the levels equation.

Table 16. GMM System Results (Blundell/Bond 1999):

FDI Indicator in Production Function

Number of industries with FDI $\quad 62$

Industries with positive sign for FDI $\quad 55$

Industries with positive sign for FDI, significant at 10\% level 39

Industries with Sargan-Test not rejected at 5\% level 44

Industries with Second-Order Autocorrelation rejected at 5\% level 55

Number of FDI Recipients $\quad 185$

Number of FDI Recipients in Industries with positive and significant sign for FDI 149

Average magnitude of the estimated effect of FDI on plant productivity $\quad 26 \%$ pts

Overall Number of Observations in Estimation

99,964 
A summary of the GMM results is presented in Table 16. The coefficient on the FDI variable shows a positive sign in 55 of the 62 industries. 73 percent of the acquired plants analyzed in Section 7 belong to industries where this effect is positive and significant at the 10 percent level. The estimated magnitude of the effect on the plant productivity averages at around 26 percentage points with the median effect of 23 percentage points. These estimates are broadly in line with the results presented in Section 7. The GMM results hence confirm our previous results that foreign ownership per se has a significant impact on plant productivity.

\section{Conclusions}

A large empirical literature searches for the evidence of knowledge spillovers from foreign direct investment. Implicit to this analysis lies the assumption that foreign ownership per se conveys some intangible advantages whose proximity can be beneficial to domestic firms. Yet there is no robust empirical confirmation that this assumption holds.

This study fills this gap in the literature by examining the causal relationship between foreign ownership and plant productivity using a Census of Indonesian Manufacturing Plants. Our aim is to distinguish between the possibility of foreign investors acquiring above-average performers (the gifted kids explanations) and genuine performance improvements resulting from foreign ownership (the pushy parent hypothesis). To make a clear distinction between correlation and causality, our analysis focuses on plants that change from domestic to foreign ownership and combines the difference-in-differences approach with a propensity score matching.

The results suggest that foreign ownership brings significant benefits to Indonesian plants. The acquired plants experience a faster growth in total factor productivity than their counterparts remaining in domestic hands. They also grow faster in terms of output and employment, invest more and increase employee wages faster. Finally, they become more integrated into the international economy, both in terms of exports and in terms of sourcing inputs from abroad.

Many developing countries strive to attract FDI inflows in the hope of stimulating economic growth through knowledge transfer associated with foreign investment. Recently, the Economist magazine pushed this view even further by stating that "the fate of the [Indonesian] economy rests on attracting foreign investment." positive view of FDI and benefits it may bring to Indonesia and other developing countries are reinforced by the results of this study which indicate that foreign investors outperform indigenous plants and that foreign ownership per se lies at the

\footnotetext{
36 "Time to deliver: A survey of Indonesia." December 11, 2004, p. 4.
} 
root of this advantage. This finding is important as the existence of a positive direct effect is a precondition for knowledge spillovers from FDI. 


\section{References}

Aitken, Brian and Ann Harrison (1999). Do Domestic Firms Benefit from Direct Foreign Investment? Evidence from Venezuela. American Economic Review, v89, n3: 605-618.

Asian Development Bank (2003). Diagnostic Study of Accounting and Auditing Practices (Private Sector): Republic of Indonesia. Manila, Philippines. Available online at http://www.adb.org.

Arellano, Manuel and Stephen Bond (1991). Some Tests of Specification for Panel Data: Monte Carlo Evidence and an Application to Employment Equations. Review of Economic Studies v58, n2: 277-97.

Arnold, Jens Matthias and Katrin Hussinger (2005a). Exports vs. FDI. Empirical evidence using German firm level data. ZEW Working Paper, Centre for European Economic Research, Mannheim, Germany.

Arnold, Jens Matthias and Katrin Hussinger (2005b). Export Behavior and Firm Productivity in German Manufacturing. A Firm-level Analysis. Forthcoming in Review of World Economics/Weltwirtschafliches Archiv, v141, n2.

Barba Navaretti, Giorgio and Castellani, Davide (2004), "Investments Abroad and Performance at Home: Evidence from Italian Multinationals". CEPR Discussion Paper No. 4284.

Barba Navaretti, Giorgio and A.J. Venables with F. Barry, K. Ekholm, A. Falzoni, J. Haaland, K-H. Midelfart, \& A. Turrini (2004). Multinational firms in the world economy, Princeton University Press (forthcoming).

Becker, Sascha and Andrea Ichino (2002). "Estimation of Average Treatment Effects Based on Propensity Scores," Stata Journal, v2, n4: 358-377.

Benfratello, Luigi and Alessandro Sembenelli (2002). Foreign Ownership and Productivity: Is the Direction of Causality So Obvious? Centro Studi Luca d'Agliano Development Studies Working Paper 166.

Biro Pusat Statistik (BPS). Statistical Yearbook Indonesia, various editions, Jakarta.

Blundell, Richard and Steve Bond (1999). GMM Estimation with Persistent Panel Data: An Application to Production Functions. Working Paper W99/04, Institute for Fiscal Studies, London.

Blundell, Richard and Monica Costa Dias (2000). Evaluation Methods for NonExperimental Data. Fiscal Studies v21, n4: 427-68.

Chari, Anusha, Paige Parker Ouimet and Linda Tesar. 2004. "Acquiring Control in Emerging Markets: Evidence from the Stock Market," NBER Working Paper 10872 .

Conyon, Martin J., Sourafel Girma, Steve Thompson and Peter Wright (2002). The Productivity and Wage Effects of Foreign Acquisition in the United Kingdom. Journal of Industrial Economics v50, n1: 85-102. 
Djankov, Simeon and Bernard Hoekman (2000). Foreign Investment and Productivity Growth in Czech Enterprises. World Bank Economic Review v14, n1: 49-64.

Doms, Mark E. and J. Bradford Jensen (1998). Comparing Wages, Skills, and Productivity between Domestically and Foreign-Owned Manufacturing Establishments in the United States. In: Geography and ownership as bases for economic accounting : 235-55. NBER Studies in Income and Wealth, vol. 59. Chicago and London: University of Chicago Press.

Dunning, John H. (1993). Multinational Enterprises and the Global Economy. Wokingham, England: Addison-Wesley Publishing Company.

Evenett, Simon and Alex Voicu (2003). "Picking Winners or Creating Them? Revising the Benefits of FDI in the Czech Republic," Oxford University, mimeo.

Fauzias, Mat Nor and Shamsubaridah Ramlee (1995). Post Performance of Malaysian Acquired Firms: A Preliminary Study. Jurnal Pengurusan v14, $\mathrm{n} 1: 11-25$.

Filer, R., O. Schneider and J. Svejnar (1995). Wage and non-wage labour cost in the Czech Republic: The impact of fringe benefits, CERGE-EI Working Paper No. 77, Prague.

Girma, Sourafel and Holger Görg (2003). Multinationals' productivity advantage: Scale or Technology? GEP Research Paper No. 2002/07. University of Nottingham.

Girma, Sourafel, Holger Görg and Eric Strobl (2004). Exports, international investment, and plant performance: Evidence from a non-parametric test. Economics Letters, v83, n3: 317-324.

Girma, Sourafel, David Greenaway and Richard Kneller (2003). Export Market Exit and Performance Dynamics: A Causality Analysis of Matched Firms. Economics Letters v80, n2: 181-87

Goeltom, Miranda S. (1995). Indonesia's financial liberalization: An empirical analysis of 1981-88 panel data. Current Economic Affairs Series. Singapore: Institute of Southeast Asian Studies, ASEAN Economic Research Unit.

Görg, Holger and Eric Strobl (2001). "Multinational Companies and Productivity Spillovers: A Meta-Analysis." Economic Journal, v111, n475: 723-739.

Griffith, Rachel (1999). Using the ARD Establishment Level Data to Look at Foreign Ownership and Productivity in the United Kingdom Economic Journal v109, n456.

Griffith, Rachel and Helen Simpson (2001). Characteristics of foreign-owned firms in British manufacturing. Institute for Fiscal Studies, IFS Working Papers: W01/10.

Haddad, Mona and Ann Harrison (1993). Are There Positive Spillovers from Direct Foreign Investment? Evidence from Panel Data for Morocco. Journal of Development Economics v42, n1: 51-74. 
Harris, Richard D. (2002). Foreign Ownership and Productivity in the United Kingdom--Some Issues When Using the ARD Establishment Level Data. Scottish Journal of Political Economy v49, n3: 318-35.

Harris, Richard and Catherine Robinson (2003). Foreign Ownership and Productivity in the United Kingdom Estimates for U.K. Manufacturing Using the ARD. Review of Industrial Organization v22, n3.

Harris, John R., Fabio Schiantarelli and Miranda G. Siregar (1994). The Effect of Financial Liberalization on the Capital Structure and Investment Decisions of Indonesian Manufacturing Establishments. World Bank Economic Review v8, n1: 17-47.

Heckman, James J. (1979). Sample Selection Bias as a Specification Error. Econometrica v47, n1 : 153-61.

Helpman, Elhanan, Marc J. Melitz and Stephen R. Yeaple (2004). Export Versus FDI with Heterogeneous Firms, American Economic Review, v94, n1: 300316.

Hill, Hal (2000). The Indonesian economy (Second edition). Cambridge; New York and Melbourne: Cambridge University Press.

International Finance Corporation (1997). Lessons of Experience: Foreign Direct Investment, Washington DC.

Javorcik, Beata Smarzynska. (2004). "Does Foreign Direct Investment Increase the Productivity of Domestic Firms? In Search of Spillovers through Backward Linkages," American Economic Review, v93, n3: 605-627.

Kertesi, G. and J. Köllö. (2001). A gazdasági átalakulás két szakasza és az emberi töke átértékelödése, (Two phases of economic transformation and the revaluation of human capital). Közgazdasági Szemle v47: 897-919.

Leuven, Edwin and Barbara Sianesi (2003). "PSMATCH2: Stata module to perform full Mahalanobis and propensity score matching, common support graphing, and covariate imbalance testing". http://ideas.repec.org/c/boc/bocode/s432001.html. Version 1.2.3.

Levinsohn, Jamesand Amil Petrin (2003). Estimating Production Functions Using Inputs to Control for Unobservables Review of Economic Studies v70, n2: $317-41$.

Levinsohn, James, Amil Petrin and Brian Poi (2004). Production Function Estimation in Stata Using Inputs to Control for Unobservables. Stata Journal, v4, n1.

Lipsey, Robert E. and Fredrik Sjoholm (2004). Foreign direct investment, education and wages in Indonesian manufacturing Journal of Development Economics, v73, n1: 415-422.

Markusen, James R. (1995). "The Boundaries of Multinational Enterprises and the Theory of International Trade," Journal of Economic Perspectives, v9, n2: 169-189. 
Olley, G. Steven and Ariel Pakes (1996). The Dynamics of Productivity in the Telecommunications Equipment Industry. Econometrica v64, n6: 1263-97.

Ramachandaram, Vijaya (1993). "Technology transfer, Firm Ownership, and Investment in Human Capital," Review of Economics and Statistics 75(4): 664-670.

Rosenbaum, Paul R.and Donald B.Rubin (1984). Estimating the Effects Caused by Treatments: Comment [On the Nature and Discovery of Structure]. Journal of the American Statistical Association v79, n385: 26-28.

Saggi, Kamal (2002). Trade, Foreign Direct Investment, and International Technology Transfer: A Survey. World Bank Research Observer v17, n2: 191-235.

World Bank (1997). Malaysia: Enterprise Training, Technology, and Productivity. World Bank. Washington, DC. 


\section{Figures}
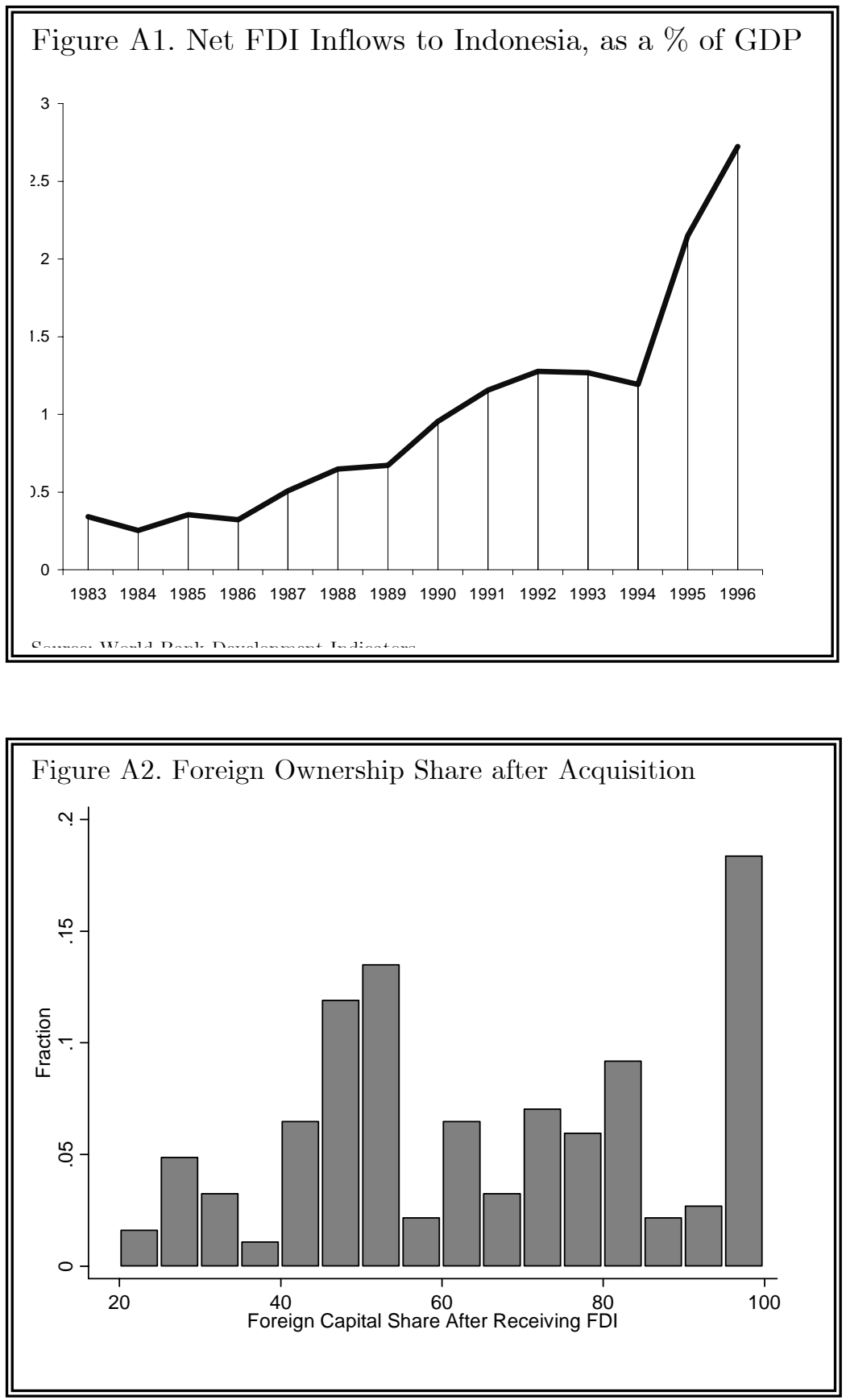


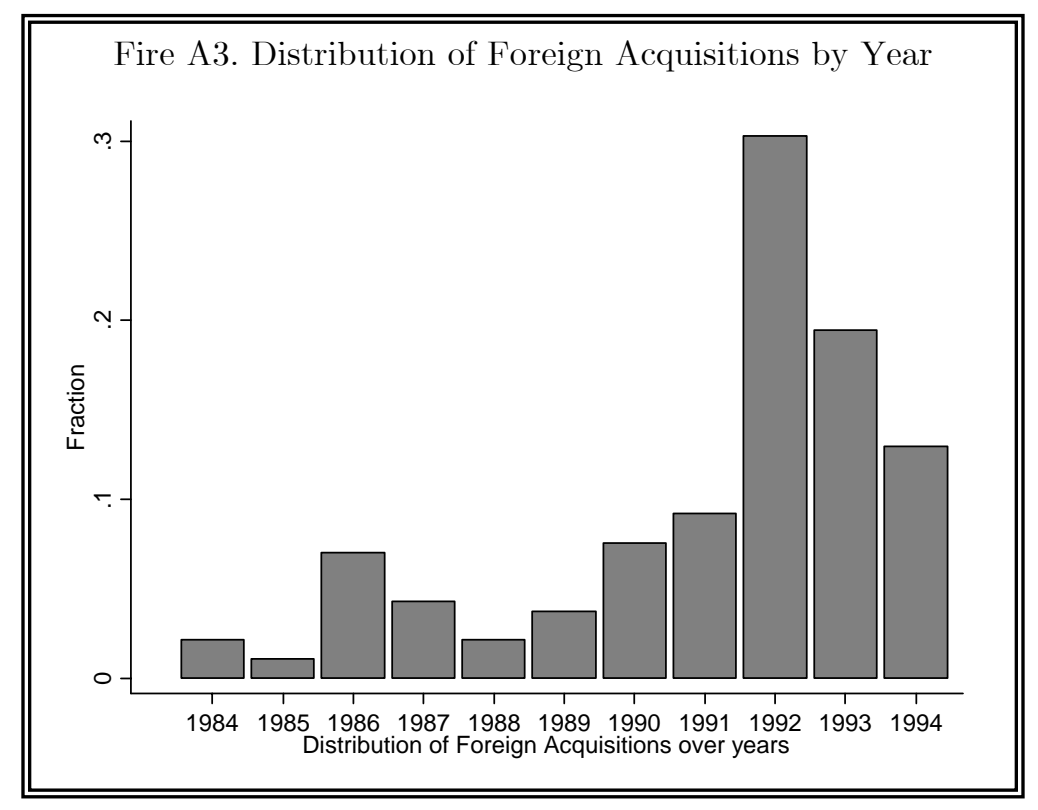

Figure A4. Distribution of Foreign Acquisitions by Sector

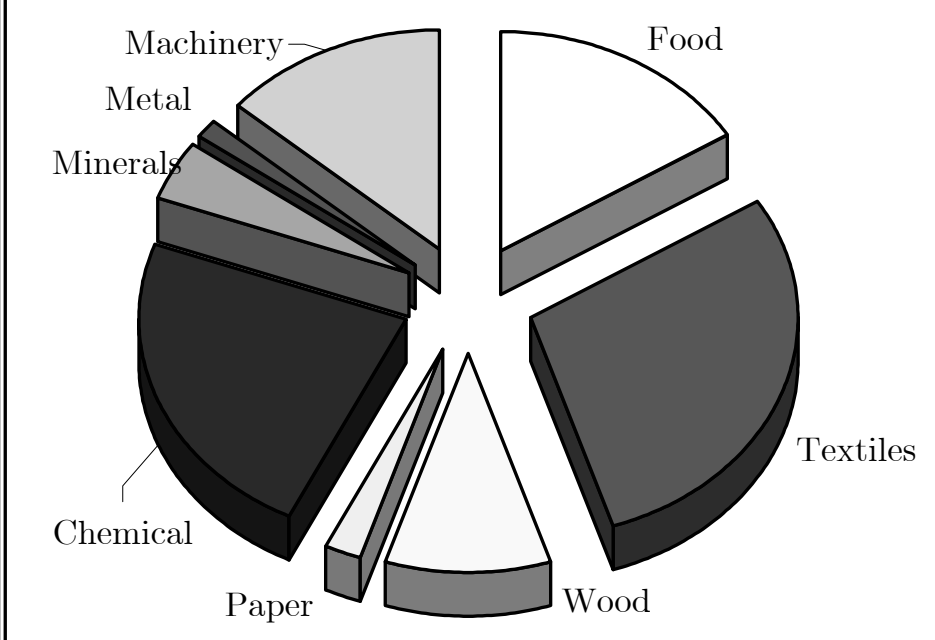




\section{Appendix}

\section{Additional Evidence on Domestic vs. Foreign Acquisitions in Indonesia}

The Securities Data Corporation Mergers and Acquisitions Database lists 47 domestic acquisitions in Indonesia between 1988 (the first year of data availability) and 1994 (the last year in which acquisitions are considered in our sample), of which 19 took place in manufacturing sectors. For 6 of the 19 cases we managed to obtain additional data from the Worldscope database (1995 release). As Worldscope does not contain sufficient information to calculate TFP figures, in the table below we consider the evolution of the ratio of cost of goods sold (COGS) to sales, which gives some indication of the efficiency with which inputs are being utilized. The COGS is defined as the wage and material costs. The ratio of COGS to sales is normalized by the average value observed in a given industry and year. The industry averages are calculated based on the data from the Indonesian Census of Manufacturing. For comparison purposes, we calculate the analogous figures for the plants acquired by foreign investors, considered in Section 7.

The available information, albeit limited, suggests that foreign acquisitions may be associated with greater performance improvements than domestic takeovers. A performance improvement is defined as a decrease in the ratio of COGS to sales (relative to the industry average). Out of six firms considered, only two experience a decline in the ratio and the decline does not take place until two year after the acquisition. Thus on average a domestic acquisition is associated with a deterioration in firm performance. In contrast, plants which undergo foreign acquisitions (considered in Section 7) experience on average a decline in the ratio in the year of the acquisition as well as in the following period. Two years after the takeover the ratio increases slightly but remains well below the pre-acquisition period.

Table 1A. Cost of Goods Sold over Sales, normalized by the industry average

\begin{tabular}{|c|c|c|c|c|}
\hline & $\mathrm{t}-1$ & $\mathrm{t}=0$ & $\mathrm{t}+1$ & $\mathrm{t}+2$ \\
\hline Domestic Acquisition 1 & 0.593 & 0.912 & 1.214 & 1.269 \\
\hline Domestic Acquisition 2 & 1.153 & 1.149 & 1.176 & 1.116 \\
\hline Domestic Acquisition 3 & 1.062 & 1.026 & 1.087 & 1.102 \\
\hline Average of $1-3$ & 0.936 & 1.029 & 1.159 & 1.162 \\
\hline Domestic Acquisition 4 & & 0.561 & 0.726 & 0.833 \\
\hline Domestic Acquisition 5 & & 0.811 & 0.961 & 0.924 \\
\hline Domestic Acquisition 6 & & 0.736 & 0.974 & 1.068 \\
\hline Average of $4-6$ & & 0.703 & 0.887 & 0.942 \\
\hline Overall average $(1-6)$ & & 0.866 & 1.023 & 1.052 \\
\hline Foreign Acquisitions & 0.939 & 0.925 & 0.885 & 0.901 \\
\hline
\end{tabular}

